\title{
Pengaruh persepsi kemudahan dan persepsi kemanfaatan terhadap niat perilaku untuk menggunakan SIPEJAR pada mahasiswa program studi S1 pendidikan ekonomi Universitas Negeri Malang angkatan 2020
}

\author{
Riska Alifah Amalia, Rizza Megasari* \\ Universitas Negeri Malang, Jl. Semarang No. 5 Malang, Jawa Timur, Indonesia \\ *Penulis korespondensi, Surel: rizza.megasari.fe@um.ac.id
}

Paper received: 6-8-2021; revised: 20-8-2021; accepted: 28-8-2021

\begin{abstract}
SIPEJAR (Sistem Pengelolaan Pembelajaran) is an official e-learning implemented by Universitas Negeri Malang in supporting the distance learning. For the new students, SIPEJAR is a system that is considered new. Because the freshmans are in a transition period perceived ease of use and perceived usefulness. This study aims to measure and analyze students behavioral intention to use SIPEJAR which is influenced by perceived ease of use and perceived usefulness. The method used in this research is a quantitative method. The subjects of this study were students of the Economic Education Program, Universitas Negeri Malang Class of 2020, who were taken using proportional sampling of 104 students. The research data was obtained from the results of the answers to the questionnaire by the the Economic Education Program, Universitas Negeri Malang Class of 2020. The results of this study indicate that perceived ease of use and perceived usefulness have a positive and significant effect on student behavioral intentions to use SIPEJAR either partially or simultaneously. Based on the results of the calculation of the effective contribution, it was found that the perceived usefulness gave a greater influence than the perceived convenience, which was $37.3 \%$ of the $54.6 \%$ of the total influence exerted by the two variables. The results of this study can be used as material for consideration for State University of Malang in developing SIPEJAR and can encourage lecturers and students to use and utilize SIPEJAR in their study.
\end{abstract}

Keywords: perceived ease of use; perceived usefulness; intention to use SIPEJAR

\begin{abstract}
Abstrak
SIPEJAR atau Sistem Pengelolaan Pembelajaran merupakan e-learning resmi yang diterapkan Universitas Negeri Malang dalam mendukung proses pembelajaran jarak jauh. Dalam penerapannya pada mahasiswa baru, SIPEJAR merupakan sistem yang dianggap baru. Hal ini dikarenakan mahasiswa baru berada pada masa transisi dari sekolah menengah dan belum terlalu mengenal sistem e-learning dalam pembelajarannya, sehingga perlu diketahui kecenderungannya terhadap penggunaan SIPEJAR. Kecenderungan atau niat perilaku tersebut dapat dipengaruhi oleh persepsi kemudahan dan persepsi kemanfaatan. Oleh sebab itu, penelitian ini dilakukan untuk menganalisis niat perilaku mahasiswa untuk menggunakan SIPEJAR yang dipengaruhi oleh persepsi kemudahan dan persepsi kemanfaatan. Pengujian dilakukan dengan mengukur pengaruh persepsi kemudahan dan persepsi kemanfaatan terhadap niat perilaku untuk menggunakan SIPEJAR baik secara parsial maupun secara simultan. Metode yang digunakan dalam penelitian ini adalah metode kuantitatif. Subjek penelitian ini adalah Mahasiswa Program Studi S1 Pendidikan Ekonomi Universitas Negeri Malang Angkatan 2020 yang diambil menggunakan proportional sampling sejumlah 104 mahasiswa. Data penelitian diperoleh dari dari hasil jawaban kuesioner oleh Mahasiswa S1 Pendidikan Ekonomi Universitas Negeri Malang Angkatan 2020. Hasil penelitian ini menunjukkan bahwa persepsi kemudahan dan persepsi kemanfaatan berpengaruh positif dan signifikan terhadap niat perilaku mahasiswa untuk menggunakan SIPEJAR baik secara parsial maupun secara simultan. Lebih lanjut, berdasarkan hasil perhitungan sumbangan efektif diperoleh bahwa persepsi kemanfaatan memberikan pengaruh lebih besar dibanding persepsi kemudahan yaitu sebesar 37,3 \% dari 54,6\% total pengaruh yang diberikan oleh kedua variabel. Hasil penelitian ini dapat digunakan sebagai bahan pertimbangan untuk Universitas Negeri Malang dalam mengembangan SIPEJAR serta dapat
\end{abstract}


mendorong dosen dan mahasiswa untuk menggunakan dan memanfaatkan SIPEJAR dalam kegiatan perkuliahannya.

Kata kunci: persepsi kemudahan; persepsi kemanfaatan; niat perilaku untuk menggunakan SIPEJAR

\section{Pendahuluan}

E-learning yang diterapkan dalam suatu lembaga pendidikan mampu menjadi salah satu daya tarik dan keunggulan lembaga untuk bersaing dengan lembaga pendidikan lain dalam memberikan kemudahan akses informasi, fleksibilitas serta efisiensi waktu dan tempat bagi mahasiswa (Edmunds et al., 2012 dalam Budhianto, 2020:14). E-learning resmi yang digunakan oleh Universitas Negeri Malang sejak tahun 2018 dalam pelaksanaan pembelajaran adalah SIPEJAR (Sistem Pengelolaan Pembelajaran). Melalui SIPEJAR, mahasiswa dapat mengakses materi kuliah yang ditempuh, berdiskusi, serta mengunggah tugas-tugas perkuliahannya. Keseluruhan fitur tersebut dapat diakses pada laman http://sipejar.um.ac.id. Sistem ini dijalankan melalui platform LMS (Learning Management System) berbasis Moodle, di mana LMS merupakan software yang dapat dimanfaatkan sebagai media untuk penyampaian materi pembelajaran serta sumber daya multimedia berbasis online dan web, selain itu mampu mengatur dan mengevaluasi proses pembelajaran, mewadahi interaksi dan kerjasama pendidik dengan peserta didik. Sementara itu, keunggulan Moodle sebagai produk LMS yang sifatnya open source sehingga bebas digunakan dan dapat diatur sesuai kebutuhan (Suartama \& Tastra, 2014:13). Selain itu, pengembangan Moodle dapat digunakan untuk mendukung penerapan e-learning dalam pembelajaran yang dapat memuat berbagai fitur seperti komunikasi, tugas, kolaborasi, kuis, dan fitur utama yang dapat digunakan untuk mengunggah berkas kebutuhan perkuliahan (Rizal \& Walidain, 2019:182).

Bagi mahasiswa baru penggunaan SIPEJAR dianggap hal yang baru dan dibutuhkan proses untuk dapat beradaptasi menggunakannya, hal ini dikarenakan mahasiswa baru yang berada pada masa transisi dari lingkungan sekolah menengah yang belum terbiasa menggunakan sistem e-learning ke lingkungan perguruan tinggi yang pada umumnya telah menerapkan sistem e-learning dalam proses pembelajarannya. Sehingga, perlu dilihat kecenderungan mahasiswa dalam menggunakan SIPEJAR tersebut. Fred Davis di tahun 1989 menggunakan model TAM (Technology Acceptance Model) untuk menjelaskan kecenderungan perilaku pengguna dalam menggunakan teknologi (Lai, 2017:26). Model TAM menempatkan dua penyebab utama dalam menjelaskan kecenderungan pengguna dalam menggunakan teknologi yaitu persepsi kemanfaatan (perceived usefulness) dan persepsi kemudahan (perceived ease of use) (Davis, 1989 dalam Murillo et.al., 2020:14). Persepsi kemudahan dijabarkan sebagai ukuran kepercayaan seseorang bahwa penggunaan sistem tertentu tidak membutuhkan banyak upaya dan kemampuan khusus. Sedangkan persepsi kemanfaatan merupakan ukuran seseorang mempercayai bahwa penggunaan suatu sistem dapat meningkatkan kinerjanya (Davis, 1989 dalam Murillo et al., 2020:3). Persepsi kemudahan dan persepsi kemanfaatan telah dibuktikan sebagai variabel yang memiliki pengaruh tertinggi terhadap niat perilaku pengguna dalam e-learning (Liu \& Wei, 2019:71). Selain itu, model TAM juga telah banyak digunakan dalam penelitian terkait kecenderungan pengguna terhadap penggunaan e-learning (Murillo et al., 2020:3). Sehingga berangkat dari permasalahan yang telah disebutkan, peneliti tertarik melakukan penelitian untuk mengetahui serta menjelaskan hubungan persepsi kemudahan dan persepsi kemanfaatan terhadap niat perilaku untuk menggunakan SIPEJAR pada mahasiswa Program Studi S1 Pendidikan Ekonomi angkatan 2020 
(mahasiswa baru). Dengan hal ini, peneliti menentukan judul "Pengaruh Persepsi Kemudahan Penggunaan dan Persepsi Kemanfaatan terhadap Niat Perilaku untuk Menggunakan SIPEJAR pada Mahasiswa Program Studi S1 Pendidikan Ekonomi Universitas Negeri Malang Angkatan $2020 "$.

\section{Metode}

Penelitian ini menggunakan pendekatan kuantitatif, dengan jenis penelitian deskriptif. Penelitian ini bertujuan untuk menganalisis pengaruh dari persepsi kemanfaatan dan persepsi kemudahan penggunaan terhadap penerimaan SIPEJAR. Di dalam penelitian ini terdapat dua variabel bebas dan satu variabel terikat. Ketiga variabel bebas yang digunakan dalam penelitian ini yaitu persepsi kemanfaatan dan persepsi kemudahan penggunaan, sedangkan variabel terikatnya merupakan kecenderungan atau keinginan untuk selalu menggunakan SIPEJAR.

Populasi dalam penelitian ini adalah seluruh Mahasiswa Prodi S1 Pendidikan Ekonomi Universitas Negeri Malang Angkatan 2020 yang berjumlah 142 mahasiswa yang terbagi ke dalam 5 offering. Dengan adanya jumlah populasi dari keseluruhan yang berjumlah lebih dari 100, sehingga diperlukan pengambilan sampel yang dilakukan berdasarkan metode proporsional sampling atau pengambilan sampel dari masing-masing offering ditentukan secara seimbang dan sebanding dengan banyaknya jumlah mahasiswa pada setiap offering.

Jenis data yang digunakan adalah data kuantitatif dengan sumber data primer. Pengumpulan data penelitian dilakukan dengan cara menyebarkan instrumen penelitian berupa angket tertutup kepada responden. Angket ini akan disebarkan kepada Mahasiswa Prodi S1 Pendidikan Ekonomi Universitas Negeri Malang Angkatan 2020 dalam bentuk link Google Form yang akan dikirimkan ke nomor Whatsapp setiap responden. Sementara itu, teknik analisis data dilakukan dengan teknik analisis analisis regresi linear berganda dan dilakukan uji t dan uji $\mathrm{F}$ untuk pengujian hipotesis.

\section{Hasil dan Pembahasan}

\subsection{Hasil}

Hasil analisis data penelitian dapat ditunjukkan oleh Tabel 1 dan Tabel 2 sebagai berikut.

Tabel 1 Hasil Uji t (Parsial)

Coefficients $^{\mathbf{a}}$

\begin{tabular}{|c|c|c|c|c|c|c|}
\hline \multirow[b]{2}{*}{ Model } & & \multicolumn{2}{|c|}{$\begin{array}{l}\text { Unstandardized } \\
\text { Coefficients }\end{array}$} & \multicolumn{3}{|c|}{$\begin{array}{l}\text { Standardized } \\
\text { Coefficients }\end{array}$} \\
\hline & & $\mathrm{B}$ & Std. Error & Beta & $\mathrm{t}$ & Sig. \\
\hline \multirow[t]{3}{*}{1} & (Constant) & 1,440 & 1,778 & & ,810 & 420 \\
\hline & Persepsi Kemudahan & 208 & ,062 & 285 & 3,376 & 001 \\
\hline & $\begin{array}{l}\text { Persepsi } \\
\text { Kemanfaatan }\end{array}$ & 343 &, 055 &, 530 & 6,281 & ,000 \\
\hline
\end{tabular}

a. Dependent Variable: Niat Perilaku

Sumber: SPSS versi 25 Hasil Pengolahan Data Penelitian

Merujuk Tabel 1, variabel persepsi kemudahan (X1) memiliki nilai signifikansi 0,001 kurang dari 0,05 atau $(0,001<0,05)$ dan thitung sebesar 3,376 lebih dari t tabel 1,983 atau $(3,376>1,983)$, maka dapat diputuskan bahwa H0 ditolak dan Ha diterima artinya persepsi 
kemudahan (X1) berpengaruh signifikan terhadap niat perilaku (Y). Sementara itu, variabel persepsi kemanfaatan (X2) memiliki nilai signifikansi 0,000 kurang dari 0,05 atau $(0,000<$ $0,05)$ dan thitung sebesar 6,281 lebih besar dari t tabel 1,983 atau $(6,281>1,983)$, maka dapat diputuskan bahwa H0 ditolak dan Ha diterima artinya persepsi kemudahan (X1) berpengaruh signifikan terhadap niat perilaku (Y).

Tabel 2 Hasil Uji F (Simultan)

\begin{tabular}{lllllll}
\multicolumn{7}{c}{ ANOVA $^{\mathbf{a}}$} \\
\hline Model & & Sum of Squares & df & Mean Square & F & Sig. \\
\hline 1 & Regression & 823,653 & 2 & 411,827 & 60,778 &, $000^{\text {b }}$ \\
& Residual & 684,363 & 101 & 6,776 & & \\
& Total & 1508,016 & 103 & & & \\
\hline
\end{tabular}

a. Dependent Variable: Niat Perilaku

b. Predictors: (Constant), Persepsi Kemanfaatan, Persepsi Kemudahan

Sumber: SPSS versi 25 Hasil Pengolahan Data Penelitian, 2021

Merujuk Tabel 2 dapat diketahui bahwa nilai signifikansi sebesar 0,000 kurang dari 0,05 atau $(0,000<0,05)$ dan nilai $F$ hitung sebesar 60,778 lebih dari $F$ tabel 3,086 atau $(60,778>$ 3,086), maka dapat diputuskan Ha diterima artinya Persepsi Kemudahan (X1) dan Persepsi Kemanfaatan (X2) berpengaruh signifikan secara simultan (bersama-sama) terhadap Niat Perilaku (Y).

Sementara itu, variabel Persepsi Kemudahan dan Persepsi Kemanfaatan memiliki pengaruh terhadap Niat Perilaku. Hal ini dapat dilihat dari hasil SPSS model summary yang menunjukkan besarnya adjusted $R^{2}$ adalah 0,546 . Hal ini menunjukkan bahwa $54,6 \%$ variabel niat perilaku dapat dijelaskan oleh variabel persepsi kemudahan dan persepsi kemanfaatan. Sedangkan sisanya sebesar 45,4\% dijelaskan oleh variabel lain diluar model penelitian. Serta dapat diketahui bahwa variabel persepsi kemanfaatan memiliki pengaruh dominan sebesar $37,3 \%$ terhadap variabel niat perilaku.

\subsection{Pembahasan}

\subsubsection{Pengaruh Persepsi Kemudahan terhadap Niat Perilaku untuk Menggunakan SIPEJAR pada Mahasiswa Program Studi S1 Pendidikan Ekonomi Universitas Negeri Malang Angkatan 2020}

Persepsi kemudahan berpengaruh positif dan signifikan terhadap niat perilaku untuk menggunakan SIPEJAR pada Mahasiswa Program Studi S1 Pendidikan Ekonomi Universitas Negeri Malang Angkatan 2020. Artinya bahwa semakin tinggi persepsi kemudahan terhadap SIPEJAR semakin tinggi pula niat perilaku mahasiswa untuk menggunakan SIPEJAR. Mahasiswa Program Studi S1 Pendidikan Ekonomi Universitas Negeri Malang Angkatan 2020 memiliki niat perilaku untuk SIPEJAR karena SIPEJAR mudah untuk dipelajari, mudah dioperasikan, mudah dimengerti, serta mudah digunakan dimanapun dan kapanpun. Temuan ini sejalan dengan penelitian Abdullah, et al. (2016:86); Chang et al. (2017:138); Arianto, dkk (2020:118); Wardani (2017:188); Ibrahim et al. (2017:885) Rahmawati \& Narsa (2019:267), Salloum, et al. (2019:12); Hasnan (2021:14) di mana persepsi kemudahan memiliki hubungan dengan niat mahasiswa untuk menggunakan e-learning. 
Lebih lanjut, penelitian ini menemukan bahwa persepsi kemudahan tidak banyak mempengaruhi niat perilaku mahasiswa Program Studi S1 Pendidikan Ekonomi Universitas Negeri Malang Angkatan 2020 untuk menggunakan SIPEJAR dalam kegiatan perkuliahan. Hal ini dikarenakan Mahasiswa Program Studi S1 Pendidikan Ekonomi Universitas Negeri Malang Angkatan 2020 yang belum memiliki pengalaman dalam menggunakan SIPEJAR masih merasa sedikit kesulitan dan belum terbiasa menggunakan SIPEJAR dalam kegiatan perkuliahannya. Kemudahan penggunaan SIPEJAR menjadi hal yang perlu dipertimbangkan, terlebih untuk memberikan kesan awal bagi mahasiswa baru dalam menggunakannya dan membantu mahasiswa untuk mempelajari serta beradaptasi menggunakan SIPEJAR. Pernyataan tersebut dibuktikan oleh Rahmawati \& Narsa (2019:267) bahwa kemudahan penggunaan sistem perlu diperhatikan dalam penerimaan awal pengguna, karena kemudahan tersebut nantinya akan mendorong mahasiswa untuk mengeksplorasi sistem lebih lanjut hingga akhirnya berdampak pada kecenderungannya untuk tetap menggunakan e-learning. Dengan demikian, kemudahan penggunaan sistem membuat mahasiswa baru mudah untuk mempelajari dan beradaptasi menggunakan SIPEJAR. Hal inilah yang membuat kecenderungan mahasiswa untuk tetap menggunakan SIPEJAR tidak terlalu memperhatikan kemudahan sistem, melainkan lebih pada faktor lain seperti kemanfaatan yang diberikan SIPEJAR.

\subsubsection{Pengaruh Persepsi Kemudahan terhadap Niat Perilaku untuk Menggunakan SIPEJAR pada Mahasiswa Program Studi S1 Pendidikan Ekonomi Universitas Negeri Malang Angkatan 2020}

Persepsi kemanfaatan berpengaruh positif dan signifikan terhadap niat perilaku untuk menggunakan SIPEJAR pada Mahasiswa Program Studi S1 Pendidikan Ekonomi Universitas Negeri Malang Angkatan 2020. Artinya bahwa semakin tinggi persepsi kemanfaatan terhadap SIPEJAR semakin tinggi pula niat perilaku mahasiswa untuk menggunakan SIPEJAR. Mahasiswa Program Studi S1 Pendidikan Ekonomi Universitas Negeri Malang Angkatan 2020 memiliki niat perilaku untuk menggunakan SIPEJAR karena SIPEJAR mampu memberikan manfaat dalam meningkatkan efektivitas, produktivitas, serta mempercepat penyelesaian urusan dan pemenuhan kebutuhan akademik seperti mendapatkan materi kuliah, mengumpulkan tugas, berdiskusi mengenai materi kuliah hingga perihal informasi perkuliahan, sehingga dengan manfaat yang dirasakan tersebut mampu membuat mahasiswa berniat untuk tetap menggunakan SIPEJAR dalam kegiatan perkuliahannya. Hasil temuan ini sejalan dengan penelitian Abdullah, et al. (2016:86); Chang et al. (2017:138); Rahmawati \& Narsa (2019:267); Dewi \& Zaky (2019:29); Salloum, et al. (2019:13); Arianto, dkk. (2020:118); Tawafak et al. (2020:825); Al-Fraihat, et al. (2020:79), di mana persepsi kemanfaatan memiliki hubungan dengan niat perilaku untuk menggunakan e-learning.

Lebih lanjut, penelitian ini menemukan bahwa persepsi kemanfaatan memberikan pengaruh lebih banyak dari persepsi kemudahan, sehingga dapat dikatakan bahwa kemanfaatan dari penggunaan SIPEJAR menjadi pertimbangan utama dalam menentukan niat perilaku mahasiswa untuk tetap menggunakan SIPEJAR. Hal ini juga berarti bahwa mahasiswa lebih memahami dan merasakan manfaat dari SIPEJAR khususnya dalam membantu memenuhi kebutuhan akademik dan menyelesaikan kewajiban akademiknya. Sehingga, manfaat yang dirasakan oleh mahasiswa akan mempengaruhi kecenderungan mahasiswa untuk tetap menggunakan SIPEJAR. Temuan tersebut didukung oleh penelitian Sukendro et al. (2020:7) dan Al-Fraihat, et al. (2020:79) yang menemukan bahwa persepsi kemanfaatan memiliki pengaruh yang kuat dalam mempengaruhi niat perilaku untuk menggunakan $e$ - 
learning. Berbeda dengan penelitian Rahayu, dkk. (2017:93) yang menyatakan bahwa manfaat yang dirasakan dari penggunaan e-learning tidak menentukan mahasiswa untuk tetap menggunakan sistem.

\subsubsection{Pengaruh Persepsi Kemudahan terhadap Niat Perilaku untuk Menggunakan SIPEJAR pada Mahasiswa Program Studi S1 Pendidikan Ekonomi Universitas Negeri Malang Angkatan 2020}

Persepsi kemudahan penggunaan dan persepsi kemanfaatan berpengaruh positif dan signifikan terhadap niat perilaku mahasiswa untuk menggunakan SIPEJAR pada Mahasiswa Program Studi S1 Pendidikan Ekonomi Universitas Negeri Malang Angkatan 2020. Artinya bahwa semakin tinggi persepsi kemudahan dan persepsi kemanfaatan terhadap SIPEJAR semakin tinggi pula niat perilaku mahasiswa untuk menggunakan SIPEJAR. Mahasiswa Program Studi S1 Pendidikan Ekonomi Universitas Negeri Malang Angkatan 2020 memiliki niat perilaku untuk menggunakan SIPEJAR karena SIPEJAR mampu memberikan kemudahan sekaligus memberikan manfaat dalam kegiatan perkuliahannya. Keduanya merupakan faktor utama yang mempengaruhi niat perilaku pengguna untuk tetap menggunakan suatu teknologi (Davis et al, 1989 dalam Dewi \& Zaky, 2019:4). Hal ini dikarenakan bahwa suatu sistem akan digunakan jika dalam penggunaannya mampu memberikan kemudahan dalam penggunaannya dan memberikan manfaat untuk menunjang kegiatan belajarnya (Fajar, 2020:118). Hasil temuan dalam penelitian ini sejalan dengan temuan penelitian dari Abdullah, et al. (2016:86); Chang et al. (2017:138); Wardani (2017:188); Salloum, et al. (2019:13); Hasnan (2021:14), yang mana persepsi kemudahan dan persepsi kemanfaatan berpengaruh terhadap niat perilaku pengguna untuk menggunakan e-learning.

Kemudahan penggunaan dan manfaat yang diberikan SIPEJAR menjadi hal yang perlu dipertimbangkan karena kemudahan penggunaan penggunaan sistem dapat membantu mahasiswa baru untuk cepat beradaptasi menggunakan SIPEJAR dan manfaat yang dirasakan dapat meningkatkan niat perilaku atau kecenderungan mahasiswa untuk tetap menggunakan SIPEJAR, terlebih bagi mahasiswa baru yang belum memiliki pengalaman dalam menggunakan sistem, maka kemudahan penggunaan dan manfaat yang diberikan oleh SIPEJAR menjadi faktor yang penting dalam menentukan kecenderungan mahasiswa untuk tetap menggunakan SIPEJAR. Temuan ini didukung dengan hasil penelitian Rahmawati \& Narsa (2019:267) yang menyatakan bahwa kemudahan berperan penting dalam memberikan pengalaman pertama pengguna dan kemanfaatan berpengaruh pada pertimbangan pengguna terkait kelanjutan untuk menggunakan sistem. Sementara itu, Salloum, et al. (2019:13) menyatakan bahwa ketika mahasiswa merasa bahwa e-learning mudah digunakan dan dapat memberikan manfaat, maka mahasiswa tersebut cenderung untuk tetap menggunakan e-learning. Sehingga, dengan kemudahan dan kemanfaatan SIPEJAR yang dirasakan oleh Mahasiswa Universitas Negeri Malang dapat mempengaruhi kecenderungan mahasiswa untuk tetap menggunakan SIPEJAR.

\section{Simpulan}

Persepsi kemudahan berpengaruh positif dan signifikan terhadap niat perilaku atau kecenderungan mahasiswa untuk menggunakan SIPEJAR pada Mahasiswa Program Studi S1 Pendidikan Ekonomi Universitas Negeri Malang Angkatan 2020. Persepsi kemanfaatan berpengaruh positif dan signifikan terhadap niat perilaku untuk menggunakan SIPEJAR pada Mahasiswa Program Studi S1 Pendidikan Ekonomi Universitas Negeri Malang Angkatan 2020. Persepsi kemudahan dan persepsi kemanfaatan berpengaruh positif dan signifikan terhadap 
niat perilaku mahasiswa untuk menggunakan SIPEJAR pada Mahasiswa Program Studi S1 Pendidikan Ekonomi Universitas Negeri Malang Angkatan 2020. Mahasiswa memiliki niat perilaku untuk menggunakan SIPEJAR yang didorong oleh kemudahan dan manfaat yang diberikan SIPEJAR, oleh sebab itu sangat disarankan bagi dosen untuk dapat memperkenalkan, menggunakan dan menjadikan SIPEJAR sebagai satu-satunya LMS dalam kegiatan perkuliahannya. Terlebih dosen dapat menjadi alasan mahasiswa memiliki persepsi kemanfaatan yang tinggi, karena secara tidak langsung mahasiswa menggunakan SIPEJAR jika ada rangsangan dari dosen.

\section{Daftar Rujukan}

Abdullah, F., Ward, R., \& Ahmed, E. (2016). Investigating the influence of the most commonly used external variables of TAM on students' Perceived Ease of Use (PEOU) and Perceived Usefulness (PU) of eportfolios. Computers in human behavior, 63, 75-90.

Al-Fraihat, D., Joy, M., \& Sinclair, J. (2020). Evaluating E-learning systems success: An empirical study. Computers in human behavior, 102, 67-86.

Alomary, A., \& Woollard, J. (2015). How is technology accepted by users? A review of technology acceptance models and theories.

Arianto, F., Susarno, L. H., Dewi, U., \& Safitri, A. F. (2020). Model Penerimaan dan Pemanfaatan Teknologi: ELearning di Perguruan Tinggi. Jurnal Teknologi Pendidikan, 8, 01.

Ayu, Q. A. (2019). Persepsi Kegunaan, Persepsi Kemudahan, dan Aksesibilitas Mahasiswa Fakultas Ilmu Pendidikan Angkatan 2018 Terhadap Penerapan SIPEJAR. KARYA DOSEN Fakultas IImu Pendidikan UM.

Baber, H. (2021). Modelling the acceptance of e-learning during the pandemic of COVID-19-A study of South Korea. The International Journal of Management Education, 19(2), 100503.

Budhianto, B. (2020). Analisis perkembangan dan faktor yang mempengaruhi keberhasilan pembelajaran daring (e-learning).

Chang, C. T., Hajiyev, J., \& Su, C. R. (2017). Examining the students' behavioral intention to use e-learning in Azerbaijan? The general extended technology acceptance model for e-learning approach. Computers \& Education, 111, 128-143.

Dewi, i. K. (2019). Faktor-faktor yang mempengaruhi penggunaan elearning systems dalam proses belajar mahasiswa universitas brawijaya. Jurnal Ilmiah Mahasiswa FEB, 7(2).

Firdaus, M. (2011). Ekonometrika Suatu Pendekatan Aplikatif Edisi Kedua. PT. Bumi Aksara. Jakarta.

Harris, I. (2017). Analisis Technology Acceptance Model (Tam) Terhadap Tingkat Penerimaan E-Learning Pada Kalangan Mahasiswa (Studi Empiris pada Universitas Internasional Batam dan UPBJJ-UT Batam). Jurnal Terapan Manajemen dan Bisnis, 3(1), 195534.

Ibrahim, R., Leng, N. S., Yusoff, R. C. M., Samy, G. N., Masrom, S., \& Rizman, Z. I. (2017). E-learning acceptance based on technology acceptance model (TAM). Journal of Fundamental and Applied Sciences, 9(4S), 871889.

Lai, P. C. (2017). The literature review of technology adoption models and theories for the novelty technology. JISTEM-Journal of Information Systems and Technology Management, 14, 21-38.

Lestari, A. S., \& Hamka, S. R. (2019). Analisis PIECES dalam Implementasi Kebijakan E-Learning di IAIN Kendari. MANAGERIA: Jurnal Manajemen Pendidikan Islam, 4(1), 103-125.

Lee, S. S., \& Wella, W. (2018). Analisis technology acceptance model penggunaan e-learning pada mahasiswa. Ultima InfoSys: Jurnal Ilmu Sistem Informasi, 9(2), 70-78.

Liu, Z., \& Wei, Z. (2019). Research on Chinese College Students' using behavior towards E-learning services based on improved TAM model. In 2nd International Conference on Social Science, Public Health and Education (SSPHE 2018) (pp. 68-71). Atlantis Press.

Munir, M. (2010). Penggunaan Learning Management System (Lms) Di Perguruan Tinggi: Studi Kasus Di Universitas Pendidikan Indonesia. Jurnal Cakrawala Pendidikan, 1(1).

Murillo, G. G., Novoa-Hernández, P., \& Rodríguez, R. S. (2020). Technology Acceptance Model and Moodle: A systematic mapping study. Information Development, 0266666920959367. 
Pangondian, R. A., Santosa, P. I., \& Nugroho, E. (2019). Faktor-faktor yang mempengaruhi kesuksesan pembelajaran daring dalam revolusi industri 4.0. In Seminar Nasional Teknologi Komputer \& Sains (SAINTEKS) (Vol. 1, No. 1).

Putra, B. T., Sulton, S., \& Soepriyanto, Y. (2019). Pengembangan Screencast sebagai Electronic Performance Support System dalam Pemanfaatan Sipejar UM. Jurnal Kajian Teknologi Pendidikan, 2(4), 252-260.

Rahmawati, R. N., \& Narsa, I. M. (2019). Penggunaan e-learning dengan Technology Acceptance Model (TAM). Jurnal Inovasi Teknologi Pendidikan, 6(2), 127-136.

Rizal, S., \& Walidain, B. (2019). Pembuatan media pembelajaran E-learning berbasis moodle pada matakuliah pengantar aplikasi komputer Universitas Serambi Mekkah. Jurnal ilmiah didaktika: Media Ilmiah Pendidikan dan Pengajaran, 19(2), 178-192.

Salloum, S. A., Alhamad, A. Q. M., Al-Emran, M., Monem, A. A., \& Shaalan, K. (2019). Exploring students' acceptance of e-learning through the development of a comprehensive technology acceptance model. IEEE Access, 7, 128445-128462.

Setiawardhani, R. T. (2013). Pembelajaran Elektronik (E-Learning) Dan Internet Dalam Rangka Mengoptimalkan Kreativitas Belajar Siswa. Edunomic Jurnal Pendidikan Ekonomi, 1(2).

Suartama, I. K., \& Tastra, I. D. K. (2014). E-learning berbasis Moodle. Yogyakarta: Graha Ilmu.

Sukendro, S., Habibi, A., Khaeruddin, K., Indrayana, B., Syahruddin, S., Makadada, F. A., \& Hakim, H. (2020). Using an extended Technology Acceptance Model to understand students' use of e-learning during Covid-19: Indonesian sport science education context. Heliyon, 6(11), e05410.

Sutadji, E., Hidayat, W. N., Patmanthara, S., Sulton, S., Jabari, N. A. M., \& Irsyad, M. (2020). Measuring user experience on SIPEJAR as e-learning of Universitas Negeri Malang. In IOP Conference Series: Materials Science and Engineering (Vol. 732, No. 1, p. 012116). IOP Publishing.

Surjono, H. D. (2013). Membangun Course E-Learning Berbasis Moodle Herman Dwi Surjono. Membangun Course E-Learning Berbasis Moodle, 1-196.

Tawafak, R. M., Romli, A. B., bin Abdullah Arshah, R., \& Malik, S. I. (2020). Framework design of university communication model (UCOM) to enhance continuous intentions in teaching and e-learning process. Education and Information Technologies, 25(2), 817-843.

Wardani, T. I. (2017). Analisis Model Kemanfaatan dan Kemudahan Teknologi dalam Menggunakan Aplikasi ELearning Edmodo. Adbis: Jurnal Administrasi dan Bisnis, 11(2), 177-189.

Yulianto, S. E. (2011). Pengaruh Persepsi Kemudahan dan Persepsi Kemanfaatan Terhadap Pemanfaatan ELearning dengan Model TAM di SMK Muhammadiyah 3 Yogyakarta. JBTI: Jurnal Bisnis: Teori dan Implementasi, 2(1), 45-62. 